\title{
Socio-Medical Viewpoints of Female Korean Students during the Covid-19 Pandemic of
}

\section{0}

\author{
* Prof. Alaric Naudé EdD PhD (Corresponding Author)
}

\begin{abstract}
Korea was one of the first countries to be directly impacted by the Covid19 (SARS Type II) virus. The swift response by the medical community was highly effective in reducing the spread of the virus: however, the education system was slower to follow suit and implement changes. This study focuses on the motivational factors of first-year (female) nursing students and analyses their opinions and thoughts on three factors: their satisfaction with the national medical response: their satisfaction with the educational system's response, and, lastly, their scientific/nursing view on gender-based and feminist responses to the global pandemic. Overall, nursing students reported satisfaction with the medical response. They were, somewhat divided on the education sector response, though satisfied with the online platform of university lectures. Female nursing students rejected gendered/feminist views on quarantine and expressed such views to be both antiscientific as well as impractical in the control of the infectious disease.
\end{abstract}

Keywords: COVID19, Nursing, Education, Feminism, Gender Studies

Introduction

In some respects, this study was a continuation of the social exploration initiated in "Female Nursing students' views toward Feminism" (Naude, 2019). The influence of media on nursing students' mindsets, including feminist ideologies, adds a particularly interesting layer of complexity to the unique circumstances and responsibilities required of a global pandemic amongst nurses. This dynamic was explored in this study.

As yet, Korea has experienced a strong degree of resistance to the radical feminist ideologies that are present in the Western world. Within a Neo-Confucian framework of etiquette and "face," Korean women have used the feminine charm of “aegyo"(愛嬌 literally: personal charms, winsomeness, attractiveness, or courtesy leading to the term 애교 공세/ 愛嬌 攻勢: attack using charm/charm offensive, a form of seductiveness) as a weapon to get ahead. This is seen in society as a strength rather than a weakness, and it is in essence a method of using chivalric standards to their advantage.

Rather than utilizing outright conflict, is common in feminism, the Korean concept of female "aegyo" involves subduing and redirecting masculine traits to gain competitive advantage socially, economically, and within relationships. This serves to set a norm for behavioral models in both males and females within Korean society. As with any relational pattern, the relational dynamic itself is not perfect, it does eliminate not only the acceptance but also survival of feminism and provides women with a powerful voice and societal influence. Feminism is generally viewed as being contrary to the greater good and as an ideology that leads to behaviors causing a loss of "face." This relates strongly to Korean etiquette and the sophisticated and complex social hierarchies that dictate interactions between individuals. (Kim)

This concept of female power by utilizing charm is presented through popular media and Korean dramas, often displaying very powerful women in supporting roles in which they possess full yet subtle control over the household, business, and relationships. At other times older women, in particular, are viewed as powerful matriarchal figures who dictate the direction of family relationships such as marriage and inheritance. This is consistent with historical models showing that within aristocratic and noble families, the so-called decisions of men were often directly influenced by their wives, concubines, or secondary wives.

* Department of Nursing Science, Suwon Science College, Suwon, Republic of Korea

Email: dr.alaricnaude@ outlook.com 
A notable example is that of the last Empress of Korea and Royal Consort, Queen Min, also known as Empress Myeongseong (明成皇后). Queen Min was the real power behind the throne (Underwood). Although King Gojong and Queen Min did not initially enjoy a close relationship, her influence and role prevented the Japanese sabotage of the Kingdom, eventually resulting in her assassination at the hands of Japanese ronin on October $8^{\text {th }}, 1895$. (Keene)

Further Confucian traditions have ensured the position of females in society. With the clan, the woman and her identity were considered important. Marriage traditions stipulated that she could not change her maiden (clan) name (and this is still the case) to that of her husband's to honor her and her ancestors. Instead, only children would receive the clan name of the father. (Caprio) Mistreatment of a woman of aristocratic and/or noble birth could therefore by extension be viewed as mistreatment of her entire clan, a serious offense.

While there have been disadvantages for women in Korean society, many depend upon the "household culture" rather than the complete social norm in Korea. An extrapolation of Korean culture from a Western perspective and interpretational lens would be not only entirely insufficient but also fundamentally flawed. Further, this paper seeks to discuss the way that women have navigated a system that, like any other system, is prone to the same flaws that have also produced disadvantages for men.

Given the unique historical and cultural context of social hierarchies in Korea, this paper attempts to expand the limited knowledge of Korean women's views outside of Korea and in a language other than Korean. It will discuss, the motivation factors of the first year (female) nursing students and analyze their opinions and thoughts on three factors: (1) their satisfaction with the national medical response during the COVID 19 outbreak; (2) their satisfaction with the educational system's response, and (3) their scientific/nursing view on gender-based and feminist responses to the global pandemic. In its essence, therefore, it is a social critique by Korean students of the prevalent ideologies in the West from a neo-Confucian cultural standpoint.

The Hypothesis

This hypothesis is based on the theoretical understanding that those individuals who choose nursing as an occupational field are likely to display high levels of empathy (McKenna et al). This, coupled with the East Asian concept of "face," (Kim et al) produced two groups of variables.

\section{Research Questions}

To what extent have nursing students motivation been affected by the COVID 19 pandemic?

To what extent are Korean nursing students resistant to feminism due to their neo-Confucian cultural ideals of social harmony?

Group A Variables: Based on Neo-Confucian concepts of "the greater good" students will:

Approve of efforts by medical staff

Approve of efforts by the education system

Disapprove of comments that cause gender division/social tension or attempt to impregnate the field of medicine with ideologies.

Group B Variables: Based on a predisposition toward viewing medicine as a science, students will be resistant to explicitly non-scientific/pseudoscientific notions.

\section{Research Methodology}

The field of nursing is globally a female-dominated profession, with no exception in Korea. Hence, this study sought to focus on the most pronounced opinion within the dominant gender group as a controlled variable (in this case females).

Female students were invited to take a digital questionnaire through a secure link. No personal information was collected to prevent the form of digital footprint and to comply with and respect students' desire for privacy. A total of 35 students partook in the study out of a student body of 110 first-year nursing students $31.81 \%$ of the total first-year nursing population.

This method can be classified as non-probability sampling as the sample population is known. It can also be classified as Judgement Sampling, which is justifiably used in this study for several factors:

a. The sample pool is known to the researcher. (students of the researcher)

b. The sample pool contains a finite population (i.e.: first-grade nursing students)

c. The sample population is comprised of a mono-ethnic group. (Korean) 
d. The sample population share one language (Korean)

To remove potential biases in responses, the students were informed that the researcher was not able to identify respondents. Students were asked to freely express their personal opinions in regards to the questions presented and to complete questions without the assistance of third parties

The survey included 10 multiple questions with the attached comment section. This dual sampling method allowed for the collection of both qualitative and quantitative data.

All questions were posed in bilingual (English and Korean) format, and students were requested to respond in their language preference, with the majority opting to use Korean.

\section{Results}

The first three questions were designed as "primers" to subsequent questions by providing context and activating critical thinking skills.

The first question in the survey asked "Do you believe that healthcare should take an impartial approach to treat people of both genders? Please explain. (건강 관리가 남녀 모두를 치료하기 위해 공정하게 접근해야한다고 생각하십니까? 설명 해주십시오")

A total of 33 (94.29\%) selected "yes." Both students who responded "no" (5.71\%) explained that partiality was needed due to "innate physiological sex differences between the genders." Meaning that all students $(100 \%)$ rejected the idea of prejudiced partiality.

The second question pertained directly to quarantine and hygiene management practices: "Do you believe that healthcare should focus on the "high risk" groups during an epidemic/pandemic? Please explain. 전염병 / 유행성 독감 기간 동안 건강 관리가“위험이 높은”그룹에 집중해야한다고 생각하십니까? 설명 해주십시오"

Twenty-three (65.71\%) responded "yes," and 12 (34.29\%) responded "no." Those desiring to focus on at-risk groups noted that this was because they felt it would be the most effective method in minimizing high potential infection routes as well as providing extra support for those more likely to be affected (e.g. elderly males, those with chronic conditions, compromised immune systems, etc.)

Those who opted not to focus on high-risk groups provided several reasons. These included: "infectious disease requires a wide scope for prevention," "only focusing on high-risk groups will not negate the spread of disease," and "all groups need to be involved to prevent the spread of infectious disease."

The final priming question was posed as follows; "Do you think Korea has an impartial healthcare system? Please explain 한국에 공정한 의료 시스템이 있다고 생각하십니까? 설명 해주십시오". (85.17\%) reported "yes," and 5 (14.29\%) reported "no."

Those who viewed medical care as impartial stated that "in an emergency room everyone is treated equally irrespective of age or gender," "although there is room for improvement, the Korean medical system is free from sexism and the national healthcare system is designed to help the needy." Further observations included, "I don't think there is another country that matches the Korean healthcare system in fairness and efficiency" and "although there are some needed improvements in support for treatment of diseases like cancer, the overall system is fair and effective."

Responses for those who answered "no" were not accurate. Although it appeared that 14.29\% disapproved of the system, the students provided clarification in the controlled variable response, $3 / 5$ students $(60 \%)$ stated they did not know and therefore selected "no." This means that those who found the system to be "partial" were $2 / 5(71 \%)$ in total. The reason given was that compared to standard medical treatments, those who suffered from injuries in heavy industries (the majority of whom are men) paid more for medical care.

The fourth question was designed as a social quantifier on the concept of "face" and the public view of nurses. A recent news example from Australia was provided, and students were invited to respond as to what effect such comments could have on the field of nursing/medicine. The information provided to students used statistics that accurate to the time the period of the survey. The question was: "Comments by a feminist politician caused controversy in the Australian Medical community. She said that females were more affected by Covid19. (Mortality rate for Australia is $70 \%$ male. Korea 54\% male.) She also said that healthcare needs to be more feminist (Australian Healthcare doctors/nurses are $98 \%$ female). Do you think that such comments are damaging to nurses 
who are working hard to control the pandemic? Please explain. 호주 페미니스트 정치인의 논평은 호주 의료계에서 논란을 일으켰습니다. 그녀는 여성이 Covid19의 영향을 더 많이 받았다고 말했다. (호주 사망률은 $70 \%$ 남성, 한국 $54 \%$ 남성) 건강 관리는 더 페미니스트해야한다고 말했다 (호주 건강 관리 의사 / 간호사는 $98 \%$ 여성). 이러한 의견이 전염병을 통제하기 위해 열심히 노력하는 간호사에게 피해를 입힌다고 생각하십니까? 설명 해주십시오".

Two respondents $(5.71 \%)$ opted out of answering this resulting in a data pool of 33 individuals of which $22(66.67 \%)$ thought it damaging to nurses and $11(33.33 \%)$ did not.

The language patterns of those who disapproved of the comments showed a different line of critical thinking, and their responses were more detailed than those who did not disapprove. However, both groups seemed to arrive at a similar conclusion regardless of whether they thought the comments were damaging. Some responses were:

"I think it is damaging to nurses because the comments of one person can affect many people in society."

"Covid19 affects both genders and the best method is to focus on stopping the path of infection as soon as possible. Trying to use such a situation to further gendered issues is harmful to already stressed nurses."

"It's not possible to know the exact trajectory of infectious disease, so I don't think gender needs to be brought into it."

"People these days pay too much attention to the media rather than reality."

"It isn't the time or place for someone who should be representing the people, to add to the pressure that nurses are already under."

"Nurses are working around the clock to fight Covid19 so they don't need comments like this."

"The individual male or female patient will have a different reaction to disease depending on their condition, making medicine more feminist is just nonsensical."

"If the general public were to believe such statements it would be damaging to trust in the nursing profession."

"Medical staff of both genders is at risk. Making only female doctors or nurses aren't going to prevent infectious diseases."

"All nurses do their utmost for patients so saying this is unfair."

Comments by students who did not view the comment as damaging revealed some indifference to the power that it could have. The answers were less detailed on average than those who thought it damaging. Many of these students did not disagree because they thought that the remise was incorrect but rather because they did not view the messages to be influential or significant. Some responses included:

"Covid19 isn't a gendered issue so I don't think people will pay attention."

"Nurses have sworn to do our job to protect society, we uphold this regardless of people's comments." "I don't think these comments have any impact."

"There are more women in the medical industry and health care should be fair. If so, I think firefighters and police should be more active in providing health care for men, for example, these fields have a higher percentage of men in their profession."

The fifth question was designed to measure the impact of the pandemic on the mental status and motivational factors of nursing students as the entire education system had migrated to an online platform. The question was posed, "How has the Covid19 pandemic affected your desire to be a nurse? COVID 19 유행성 독감이 간호사가 되려는 욕구에 어떤 영향을 미쳤습니까?” Three possible responses were given; "Positively affected 긍정적 인 영향, Not affected 영향을받지 않았, Negatively affected 부정적인 영향”, Each selected-response required a long answer response. 


\begin{tabular}{llr} 
ANSWER CHOICES & RESPONSES & \\
\cline { 1 - 1 } Positively affected 긍정적 인 영향 & $60.00 \%$ & 21 \\
\cline { 1 - 1 } Not affected 영향을받지 않았다 & $25.71 \%$ & 9 \\
\cline { 1 - 2 } Negatively affected 부정적인 영향 & $14.29 \%$ & 5
\end{tabular}

Figure 1. Affect of Covid19 on Nursing Student Motivation

Interestingly, rather than dissuading students, the pandemic had resulted in increasing the desire of students to become nurses in $60 \%$ of cases. A variety of responses were forthcoming displaying a strong degree of empathy and the neo-Confucian concept of "the greater good."

"I want to become someone who helps others."

"Seeing nurses working so hard to stop the spread of Covid19 and seeing the news say that nurses are in short supply only makes me want to become a nurse even more so that I can help in similar situations."

"Even though I am afraid, I saw the hard work of other nurses and want to follow their example."

"It allowed me to reflect on what type of nurse I want to be." In the Korean linguistic sense, the language denotes not the type of nurse in the form of specialization but rather the personal quality or psyche of the individual in their approach to the task.

"Most of the nurses who worked in negative-pressure rooms voiced that when the patients left the hospital, they (the nurses) were full of pride in their efforts. These comments make me highly motivated, and have a sense of duty of 'Nursing'."

"Seeing the many nurses who volunteered to work in the danger zone was deeply impressive and motivating."

"I felt not only grateful for nurses who came before me but also motivated to do the same."

There were some responses of note among those who said they were not affected by the recent pandemic.

"I just worried about the spread, it didn't affect my desire."

"Pandemics can occur at any time, dealing with that is part of nursing so it didn't affect me."

"Fighting infectious disease is part of nursing so it comes with the territory."

"It didn't affect me but I had mixed emotions, I thought I can be of use in a similar situation but worried about the potential that I could infect my family by mistake."

Those who said that they had been demotivated stated that the demotivational factors where mostly fear or concern for the undesirable actions of third parties.

"Seeing that nursing is ground zero for pandemics made me afraid."

"I became afraid when I saw the main brunt of effort was by nurses and that they lacked support."

"I am more negatively than positively affected due to a report I saw on the news detailing the terrible conditions nurses are facing."

"I was discouraged when I saw medical staff in protective gear but others not following basic hygiene procedures."

The sixth question addressed student perception as to the response of the medical sector to the Covid19 pandemic in Korea. The question was formulated as "What is your opinion on the response of nurses to COVID 19 in Korea? 한국의 COVID 19 에 대한 간호사의 반응에 대한 귀하의 의견은 무엇입니까?” with the option of selecting "Excellent 매우 좋아, Good 좋아, Neutral 보통, Poor 부족함, Very Poor 매우 부족함. One student opted not to participate in the question yielding a sample size of 34. Interestingly, unanimous approval was shown for medical sector response with 30 (88.24\%) viewing it as "excellent" and $4(11.76 \%)$ viewing the response as "good." 
Figure 2. Approval ratings by nursing students of the medical system response to Covid19

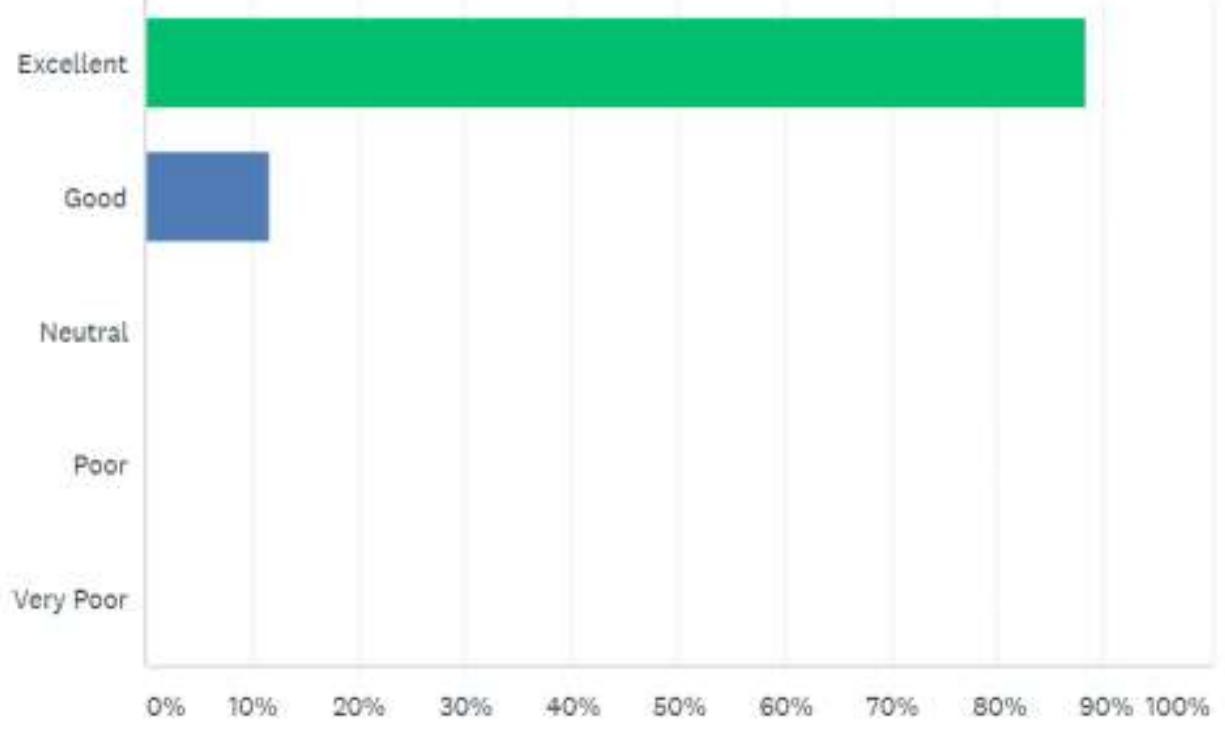

Again for the seventh question in the set, the sample size was reduced to 34 as one student did not participate. Given the unique situation under Covid19, there was a delay in the education sector's response, which seemed to have caused consternation among students. When asked "What is your opinion on the response of the education system to COVID 19 in Korea? 한국의 COVID 19 에 대한 교육 시스템의 대응에 대한 귀하의 의견은 무엇입니까?" Students responded with one of five options with the same wording as that in question five.

Figure 3. Student opinions on the response of the education system during Covid19.

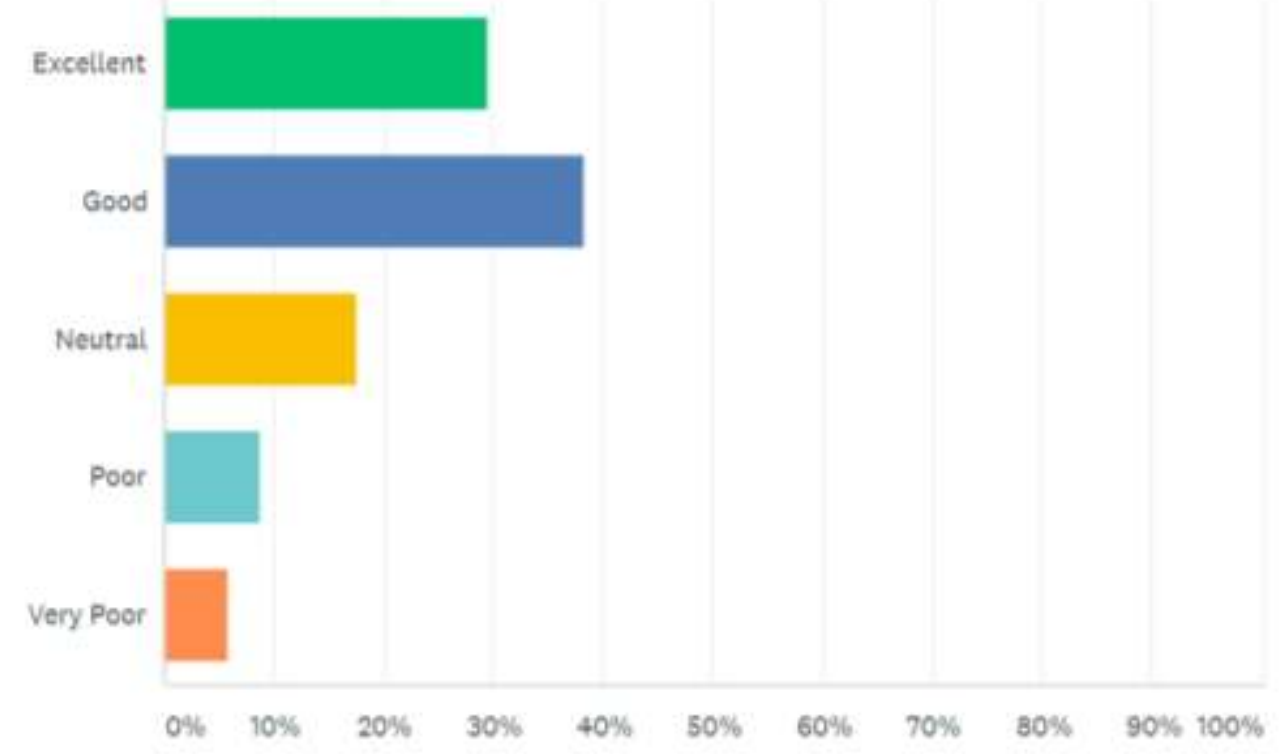

Ten $(29.41 \%)$ Students viewed the response of the system as "excellent" and 13 (38.24\%) viewed it a "good," bringing the total positive view to $23(67.65 \%)$. Neutral views made up 6 $(17.65 \%)$ and "poor" at $3(8.82 \%)$ with "very poor" getting the least responses at $2(5.88 \%)$. This aligns with this study's first hypothesis.

The responses for the eighth question were of interest because they opposed the common preCovid19 sentiment. Before the pandemic, most students expressed a preference for face to face lectures, a trend that reversed during the pandemic, although not altogether, "Do you prefer online lectures or face to face lectures? 온라인 강의 나 대면 강의를 선호합니까?” A total of $12(35.29 \%)$ 
stated that they preferred lectures in a face to face setting, although as written responses show, they were willing to forgo this option due to the pandemic.

"I have many assignments so I feel a face to face class would be better, although only after this dies down."

"I think in-person lectures are more beneficial."

"I would prefer face to face lectures so that I could ask questions and get feedback on my work straight away."

"I prefer talking with others or discussing issues, exchanging opinions. Also, there are some sides that online can't replace 'face to face' lectures!"

"I would prefer an in-person lecture that also uses multimedia."

Those who were in favor of online lectures comprised $22(64.71 \%)$ which was much higher than anticipated. A common theme was that students desired to avoid spreading the virus. One student wrote "For face-to-face lectures, we have to use public transportation or a shuttle bus. I think that if relatively many people move together in a confined space, they will be more vulnerable to infection. Currently, people are becoming reinfected, and new ones continue to come out. I think online lectures are effective to help prevent the proliferation of the virus. Online lectures are essential to protect students, their families, and countless people they will encounter while commuting to school. Currently, most of our university students and freshmen are hoping to conduct online lectures during the semester. If even one confirmed case occurs during the face-to-face lecture, you may not be able to have a face-to-face talk lecture for a very long time. There is no clear alternative if after the faceto-face lecture there is a resulting outbreak, and students are very anxious. I think online lectures will be enough for quality learning."

"It would be more practical to have online classes while the pandemic lasts."

"There is no vaccine yet and there are people who have no symptoms, but I feel uneasy because people are not wearing masks due to insensitivity to others. I think online is better."

"Schools that want to have face to face lectures when it is not even over yet are ignorant. It is only seen as trying to make students pay tuition fees. For students, the school would have conducted cyber lectures. I feel that the school's handling of the situation is a shame."

The ninth question was open-ended, and students were able to provide their ideas freely. These ideas were categorized according to the criteria to which they pertained. "Which group do you think has been the most severely affected by COVID19 in Korea? 한국에서 COVID19 의 영향을 가장 많이받은 그룹은?"

\section{Most Affected Groups}

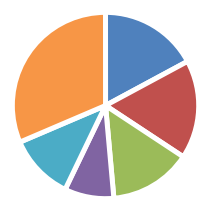

- Elderly (6/17.14\%)

- 3rd Grade HS Sts (6/17.14\%)

- Aviation \& Hospitality (5/14.28\%)

- Pts with Chronic Disease (3/8.57\%)

- Medical Staff $(4 / 11.42 \%)$

- Other $(11 / 31.42 \%)$

The final question served as a form of variable control to students' previous responses about making medicine more feminist. The question inquired, "Do you think only one gender can control a pandemic? Please explain 한 성별 만 유행성 질병을 통제 할 수 있다고 생각하십니까? 설명 해주십시오". Response options were "possible" or "impossible," along with a section for a detailed 
answer. Only three respondents $(8.57 \%)$ thought that focusing on one gender could stop the spread of the disease. Two students mentioned that, in their opinion, men were less likely to follow proper handwashing routines. However, one student stated that she felt that women posed more risk due to the Korean habit of groups of female friends traveling together for tourism, etc.

An overwhelming majority of $32(91.43 \%)$ selected that it would be "impossible" to control the virus by focusing on only one gender.

"I think it's impossible. I fail to understand where the logic is coming from in the opinion that only one gender can control a pandemic. Regardless of gender or age, epidemic diseases can be contracted by everyone, so there seems to be no way to control them other than to take precautions."

"I think it's impossible as infectious diseases can infect anyone."

"I think that the epidemic isn't just about one gender, it's about managing everyone so we can lower our chances of getting it."

"I think epidemic diseases are not controllable by one gender, but only when everyone's efforts gather, regardless of gender."

"An epidemic that affects only one gender would be possible, but the current epidemic does not affect only one gender."

"This can't be happening in our life. Pandemic means a disease is widely spread around the world, so only one gender is attacked and other is being controlled can't be the basis of a pandemic. Moreover, people are exposed to the disease, and there are many mutations, so it is impossible to prevent by controlling only one gender."

Other students were more forceful in their opinions:

"I don't understand how the heck they expect a disease to identify which gender it wants to infect, how is picking one gender to control going to make things better?"

"I don't think the virus particularly cares who you are and what your gender is."

Discussion

The basic concepts mentioned in the hypothesis proved to be correct; however, the results did differ in the percentages and types of responses that the researcher has anticipated.

\section{Table 1. Student Approval Aligned With Hypothesis}

\begin{tabular}{lcc}
\hline Group A Variable & Approve & Disapprove \\
\hline Medical System & $\checkmark$ & $/$ \\
Education System & $\checkmark$ & $/$ \\
Gendered Statements & $/$ & $\checkmark$ \\
\hline
\end{tabular}

The social disposition to avoid conflict in the Korean language forms as an extension of behavior was noted following the findings of Kim et al (1998). Yet. Individual students were noted to deviate from this social norm by utilizing stronger, more emotive language. As seen from the work of Sohn et al, the Korean language shows a multilayered understanding of emotions with single words capable of conveying more than one emotion at a time. This presents an unknown variable, certain Korean dialects are known to display more emotion than others. Hence, if the students' place of birth were known, it would allow for the evaluation of regionalized reactions to social issues. To avoid such a blind spot, future studies could attempt to ask additional questions such as place of birth to more clearly ascertain the dialect. Conversely, if it is expected that the majority of students have grown up in the same province, obtaining the birth provinces of parents could prove useful insights.

The first three primer questions permitted the extrapolation of a microcosm of attitudes among female nursing students. The majority having viewed the system as unbiased would therefore also suggest a lack of support for the implementation of the gendered policy. Those critical of the system also indicated favor for men, having noted that men who suffer from injuries while working dangerous jobs paid more for healthcare. This was not expected, and future studies could potentially explore the view of fairness per assigned social demographic units. Further, this would set the recurring pattern of answer sets that lean heavily towards perceptions of the greater good, preserving social order through hierarchies, and "saving face."

Contrary to Western Feminist theories that hierarchies are unnecessary or harmful (Ianello), Korean cultural attitudes welcome hierarchies, and they are only seen as harmful when they lack balance (e,g, in cases where rich or powerful individuals abuse those of a lower hierarchical rank). Such abuse is also seen as a cause for loss of face. Hence, the hierarchical system includes built-in 
checks and balances that ensure social stability. Thus, students overwhelmingly opposed the comments by the feminist politician as they were regarded detracting from the work of nurses, thereby belittling the nursing profession causing a loss of face. Given the language patterns used, students expressed that the comments showed a lack of sensitivity to community cohesion during a medical crisis and were therefore inappropriate. Those that viewed the comments as non-damaging had a more indifferent view as to how the public would receive such comments. They felt that nurses, along with the general public, would not pay attention to such comments. This sentiment is formed based on a Koreacentic concept and understanding of social phenomena. These students used language patterns indicating that the comments were devoid of practicality and were unscientific, therefore nonthreatening. Both answer sets are supportive of control variable group B.

Of special interest were the results of motivation during the Covid19 pandemic. Students displayed even more willing to help the community with a total motivation increase of $45.71 \%$ (60\% motivated; $14.29 \%$ demotivated). If the neutral party comprising of $25.71 \%$ were considered to be "already motivated," then the percentage of motivated students increased. However, given that the aim was to assess change in motivation, either positive or negative, the choice to deduct the neutral party from the overall extrapolation is valid.

It can be deduced that isolation during the Covid19 did not dampen the drive to study, which raises questions that could be further explored and serve as the basis of future hypotheses such as "How was students' overall mental health impacted by isolation while studying?" "Have notions about online study changed now that students have experienced online lectures and coursework?" and "How did students of different grade levels compare in motivation or demotivation statistics?" Another area of exploration could be a comparative analysis of motivational factors and opinions of both male and female students.

When asked about their views on the response of the medical sector, there was unanimous approval. This question was somewhat flawed in its design since it combined the approval ratings of government-stipulated responses and the response of the medical system itself, two entirely separate entities. Separation of these items would have provided a data set that allowed for more in-depth analysis.

The majority perceived the education system to have handled the pandemic well; however, the combined total of students who disapproved (14.7\%) confirms that not all students were pleased. This question was also problematic due to lacking a long response section which was an oversight in design, thus missing an opportunity to collect valuable data for understanding exactly why students held the views they did about the education sector. This information would have served as a point of entry into identifying improvements that could be made in the migration of lectures from the fac-toface to an online setting.

The question then naturally arose as to the exact preferences of Korean students regarding the method of study, online or in-person. As previously stated, the trend toward online learning was not well-established pre-Covid19. Since, the majority found that online classes had become more desirable for reasons of hygiene (some students also worried that they could inadvertently infect others), convenience, as well as transportation. It would be of interest to gauge how many students would prefer continuing with this model of a lecture. This information was not collected during data acquisition.

The opinion was that the most affected groups were the Elderly and students, reflecting the strong neo-Confucian notion of filial piety (Lew et al) and respect for elders as well as the high regard for and esteem placed on education (Lee). This was another anticipated pattern based on the strong body of existing literature.

Gender control, insofar as was assessed by this study's questions, was viewed as antiscience and illogical as a method of disease control and prevention. Responses showed that students were somewhat perplexed by a belief system that tried to impose itself on medicine and therefore society as a whole. Student impressions were that ideology ought to be left in its place and that medicine should focus on medicine.

Some potential weaknesses in this study include the size of the data sample. Although the sample to population ratio was satisfactory, greater accuracy could have been obtained through the inclusion of more participants. The study was voluntary and, therefore, could be prone to interpretational bias due to students with certain psychocognitive predispositions towards being more 
likely to volunteer and, thus, skew the results. One possible remedy is to perform pre-survey psychometric tests on students to have a more accurate measurement of underlying choices and opinions. Future studies could focus on evaluating the attitudes of more advanced nursing students or non-student nurses more acquainted with the profession and daily work. understanding questions such as these will prove more base literature on this subject.

\section{Conclusion}

The study suggests that female nursing students had views that were shaped by neo-Confucian concepts of social harmony. Students reported strong trust in the health care system as an unbiased institution. As hypothesized, students showed majority approval of medical and education sector responses. They also displayed an aversion to challenges to social hierarchies and gendered approaches to health care in the case of a pandemic disease. Motivation to continue with their studies to become nurses increased in response to the outbreak of Covid19 along with a sense of responsibility and desire to serve and protect the wider community. As a result, the trajectory for the nursing field in Korea remains positive despite the pandemic.

\section{Clarification of Terminology}

The researcher uses the terms gender and sex interchangeably to denote the chromosomal structure of the individual whether they be a man or woman. Non-scientific and, thereby, invalid ideological interpretations of gender were not applied to this text (such intersectional concepts of gender, are viewed as invalid in Korean society as a whole). The same application is made of terms such as man, woman, male, and female with each relating to their genetic quantifier.

\section{Acknowledgments}

Special thanks to my wife for her support and my students for their support and participation during this study. Also, special thanks must go to Nina Silander PsyD who was very supportive in giving feedback and proofreading.

\section{References}

Caprio, Mark E. (10 February 2017). "Rationalizing Korea: The Rise of the Modern State, 1895-1945 by Kyung Moon Hwang (review)". Journal of Interdisciplinary History. 47 (4): 576-578. DOI:10.1162/JINH_r_01079. ISSN 1530-9169.

Donald Keene, Emperor of Japan: Meiji and his World, 1852-1912 (New York: Columbia University Press, 2002), p. 517.

Iannello, K. (2013). Decisions without hierarchy: Feminist interventions in organization theory and practice. Routledge.

Kim, K. O. (1993). What is behind "face-saving" in cross-cultural communication. Intercultural Communication Studies, 3(1), 39-48.

Kim, J. Y., \& Nam, S. H. (1998). The concept and dynamics of face: Implications for organizational behavior in Asia. Organization Science, 9(4), 522-534.

Kim, D., Pan, Y., \& Park, H. S. (1998). High-versus low-context culture: A comparison of Chinese, Korean, and American cultures. Psychology \& Marketing, 15(6), 507-521.

Lew, S. C., Choi, W. Y., \& Wang, H. S. (2011). Confucian ethics and the spirit of capitalism in Korea: The significance of filial piety. Journal of East Asian Studies, 11(2), 171-196.

Lee, J. K. (2006). Educational fever and South Korean higher education. REDIE. Revista Electrónica de Investigación Educativa, 8(1).

McKenna, L., Boyle, M., Brown, T., Williams, B., Molloy, A., Lewis, B., \& Molloy, L. (2012). Levels of empathy in undergraduate nursing students. International Journal of Nursing Practice, 18(3), 246-251.

Naude, Alaric (2019) "Female Korean Nursing Students Views Toward Feminism" International, Journal of General Medicine and Pharmacy (IJGMP) ISSN(P): 2319-3999; ISSN(E): 23194006, 2019

Sohn, S. J., Park, M. S., Park, J. E., \& Sohn, J. H. (2012). Korean emotion vocabulary: extraction and categorization of feeling words. Korean Journal of the Science of Emotion and Sensibility, 15(1), 105-120.

Underwood, Lillias Horton (1904). Fifteen Years Among the Top-knots: Or, Life in Korea. pp. 24, 89-90. 